\title{
Commodification of Traditional Open Spaces as a Commodity and the Consequent Damage of Environmental Ethics (Case Study in Ubud Village Bali Indonesia)
}

\author{
Ida Bagus Brata, Ida Bagus Seloka, Ida Bagus Nyoman Wartha \\ A lecturer of History Education, Faculty of Teaching and Education, University of Mahasaraswati, Denpasar, Indonesia \\ Email: ibbrata@unmas.ac.id
}

How to cite this paper: Brata, I.B., Seloka, I.B. and Wartha, I.B.N. (2019) Commodification of Traditional Open Spaces as a Commodity and the Consequent Damage of Environmental Ethics (Case Study in Ubud Village Bali Indonesia). Open Journal of Ecology, 9, 171-182.

https://doi.org/10.4236/oje.2019.96014

Received: March 24, 2019

Accepted: June 22, 2019

Published: June 25, 2019

Copyright $\odot 2019$ by author(s) and Scientific Research Publishing Inc. This work is licensed under the Creative Commons Attribution International License (CC BY 4.0).

http://creativecommons.org/licenses/by/4.0/

\section{(c) (i) Open Access}

\begin{abstract}
This paper aims to examine the phenomenon of commodification of traditional open space into commodities which results in the destruction of environmental ethics. Environmental ethics places restrictions on freedom in exercising ownership rights and pays more attention to ethical obligations to the environment. The anthropocentric approach should be avoided because it only sees the environment from its commercial angles to satisfy human interests. This research critically describes the reality of the utilization of traditional open spaces in Ubud to become an economic space. The rapid influence of global culture has implications for the practices of capitalist culture within the frame of the tourism industry, resulting in cultural industries, popular culture, hedonic lifestyles and consumerism. This study used a qualitative method. The data was obtained through observation, interviews, literature studies, and documents. The results of the study revealed how traditional open spaces were produced, distributed and consumed by the market. Traditional open spaces were commercialized, traded like goods and services. Traditional open spaces, such as paddy fields, cliffs, telajakan (front part of the house complex), city parks, domestic properties, backyards, cemeteries have been turned into economic spaces to satisfy the taste of tourists. Space is controlled and commodified by capital owners to feed their economic libido while disobeying environmental ethics.
\end{abstract}

\section{Keywords}

Commodification, Traditional Open Space, Environmental Ethics 


\section{Introduction}

It is predicted that future conditions will be characterized by limited water and land resources. This means the decrease in the carrying capacity of the environment due to human population growth, shifting patterns of human life, and the impact of development activities. This phenomenon actually shows that human efforts to take full advantage of natural resources by exploiting and utilizing them using unwise methods can lead to the vulnerability of natural resources, which in turn lead to the damage to the environment eventually becoming a serious threat to the sustainability of human life in the years to come.

It should be admitted that the existence of human resources, both individual and collective, is a causal factor which largely determines the condition of the environment through institutional systems such as desa pekraman (traditional village system), banjar adat (traditional hamlet), and subak (water management or irrigation system for paddy fields). It is also true of the situation in Ubud, part of Balinese society. Suwasthawa and Cantika. (1991) state that Life in these institutions is based on the philosophy of Tri Hitakarana [1], which is the doctrine of life balance in an effort to organize a sustainable life in the future as a guide for humans in building a safe, peaceful, harmonious, and prosperous life.

The rapid influence of global culture into the area of Bali has negative implications for the practices of capitalist ideology within the frame of the tourism industry, such as the emergence of the cultural industry, popular culture, lifestyle, and consumerism culture. As stated by Picard (2006), the first contact between Ubud and the Western world took place in 1925 [2]. As a result, traditional open spaces have undergone commodification, commercialization, and touristification as adaptive forms to satisfy tourists' taste being a representation of a global culture that creates new forms, functions, and meanings.

As a result of the influence of globalization, the function of space as an identity feature of traditional Balinese open space with various values contained in it has shifted, or even it is likely to be lost. Barker (2009) and Fairclough (1995) explain that commodification of space as an economic commodity refers to the extent to which traditional open space is produced, distributed and consumed by the market [3] [4], and how the traditional space is commercialized and traded like goods and services taking various forms or display of economic spaces in an effort to get money. Brata (2014) states futher that traditional space has been commodified, starting from the production process (ideas, opinions), distributed (marketed), and consumed (utilized) in various titles of activities (business), resulting in the missing value of traditional open space [5]. [Figure 1] An example of Telajakan as a beautiful traditional open space that has not been commodified as economics spaces.

In the midst of world life trend that is increasingly moving towards bulkhead-free, namely free from ethnic, class, race, religious, and geopolitical divides, local insights are increasingly integrated into regional, national, and global ones. Globalization as a process that places people in an interdependent position has 


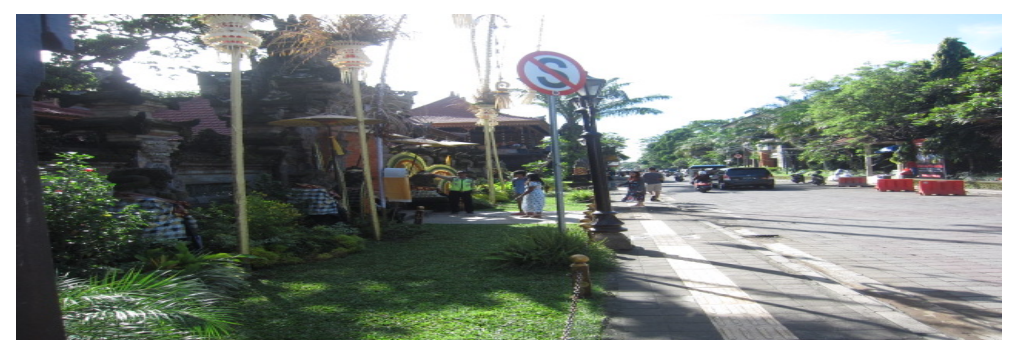

Figure 1. Telajakan as a traditional open space that has not been commodified, Photo taken by Brata, 2018.

introduced new values in the traditional environment, and therefore citizens of a tradition-supporting community always experience a process of social-structural diffraction and generalization of values, norms, and meanings contained in it.

Building various economic facilities requires spaces which now are increasingly narrower. Eventually, what is sacrificed is traditional open space, notwithstanding the fact the space is essential for all citizens of a community in the region. As a result, space has become a commodity. Therefore, the traditional open space has transmuted into private goods. Brata and Pemayun (2018) state that the global economic order has removed the boundaries of traditional open space to become a public property leading to the birth of the traditional open space market [6].

Admittedly, the arrangement of a region is very complicated and tricky, because it can potentially result in a clash between commercial and humanist approaches. Suparlan (2004) defines that the spatial layout of a region is actually the embodiment of the local culture of a community with diversity in character, distinctiveness, uniqueness, and personality [7]. Culture as capital can function normatively and operationally. Normatively, culture is expected to function to project identity, basic grip, and patterns of control so that cultural balance and resilience can be realized. Operationally, culture provides opportunities as well as being a resource to increase tourism. Therefore, the first thing that should be understood is the culture of various community groups and the influence of the values, norms, lifestyles, activities, and symbols that they adhere to regarding spatial planning in the region. In this connection it is questionable whether traditional open space is in favor of the local community, under the authority of the state or under the capital owner of the market.

\section{Preceding Studies}

Critical studies of environmental uses in Indonesia have begun to mushroom after the collapse of the New Order regime. The reform era that boosts freedom of opinion brings conducive conditions for intellectuals, non-governmental organizations (NGOs), and observers of environmental issues to criticize or reformat the problems of environmental utilization policies. The phenomenon of commodification of the environment in Bali has actually taken place since the New Order era triggered by the development of the tourism sector which places un- 
due emphasis on economic growth. A critical view of the various cases of capitalization of new traditional open spaces has been put forth in the reform era.

A good number of research into traditional open space use has been conducted, and such research has enriched our understanding of the issue in question. The study by Sukawati (2008) entitled "Spatial change of Desa Adat Ubud Gianyar in the era of globalization" found that in relation to parhyangan (spiritual relation between human and God) there was a shift in decency values, in relation to pawongan (harmonious relation between humans) there was an increase in fanaticism of social entities, and in relation to palemahan (relation between human and mother nature or environment) there was a lack of confidence in the cultural values [8]. The study carried out by Bawa (2002) on the use of cliffs along the banks of the Ayung river in the tourism industry and its implications for environmental preservation in Kedewatan Village, Ubud, found that the cliffs had been used to build various facilities in the tourism industry because of its attractive natural panorama [9]. Mudana's (2005) study of the construction of the Bali Nirvana resort (BNR) in the Tanah Lot area: hegemony and resistance in the Beraban village of Tabanan Bali discovered that such construction was faced by resistance because it was considered to ignore the concept of Tri Hitakarana which was the philosophical foundation of Bali's regional development [10]. Pujastawa (2011) found that it was essential to consider local wisdom related specifically to the effectiveness of aspects of traditional culture in controlling human behavior in utilizing environmental resources [11]. Adhika's (2011) study examined the commodification in the globalization era of the sacred area of Uluwatu temple located in Southern Badung. The results of the study showed that some of the research informants considered the commodification of the area to be a blessing, while others conceived of it as powerlessness and the occurrence of regional desecration [12]. The Kato et al. study (2019), functional analysis of plant and space in northern Denpasar, Bali, Indonesia, discovered that telajakan (front part of the house complex) was an important element in the traditional village landscape in Bali, and thus urbanization and privatization has threatened the existence of telajakan and changed species composition. Today, plants with a religious value are scant compared to exotic ornamental plants. A new form of social interaction has also emerged through the delightful telajakan when neighbors and passersby are taking photos of telajakan and posting them onto social networking services [13].

\section{Methods}

This research used qualitative method that emphasizes thick, etic-emic description, which is holistic vis-a-vis cultural perspective. The research locus was centered in Ubud Village Bali, by observing and mapping measured community activities. The observation was conducted for 12 (twelve) months from January to December of 2018, the year of 2018 being considered to facilitate the recording of information from the informants. Informants were grouped into three, 
namely: informants 1$)$ were village officials $(n=6)$, consisting of Head of Ubud village, Bendesa (Traditional Village Head) of Ubud, Pekaseh (irrigation officer), Head of North, Central, and South Ubud areas, and; informant 2) consisting of 10 people being economic actors or capital owners; and informants 3) were 15 people in Ubud.

The data used in this study were: 1) primary data, namely data and information obtained directly from the source/informant. This data was obtained by conducting direct interviews with informant groups 1, 2, and 3. Using purposive sampling techniques with a sample of 6 people from village officials, 10 tourism business owners, and 15 people in Ubud; 2) secondary data, namely data and supporting information obtained from the Office of the Village Head of Ubud.

This research is descriptive research using literature surveys, field surveys, and in-depth interviews and focus group discussions. The interviews conducted used open questions and closed questions. The data analysis used in this study included several methods according to the research objectives, such as observation and interview techniques. Observation was done directly in the research site so that you can see and observe more carefully the conditions of traditional open spaces in Ubud Bali. In-depth interview was conducted with 31 informants.

\section{Result and Discussion}

Barker (2009) defines that commodification of traditional open spaces is the process associated with capitalism where objects, quality, and signs are used as commodity materials for sale on the market [3]. Fairclough (1995) adds that it is not only that commodification is the production of commodity goods and services that are traded, but commodification also means how the goods and services are distributed and consumed [4]. Globalization has caused public indifference to all dimensions and values embraced for thousands of years due to their sinking into the ecstasy conditions of consumer society triggered by the ideology of capitalism. In this regard globalization is used as the basis in understanding the development of the commodification of traditional open space phenomena in Ubud based on the assumption that the phenomenon is inseparable from the process that places the Ubud community as part of a world community that is interconnected in various aspects of life, social, cultural, economic, technology politics and environment.

The natural attraction and uniqueness of the ecological nuances possessed by the Ubud area attracts commodification methods to the point of the physical exploitation of traditional open spaces that used to have no selling value. Since Ubud was established as one of the tourism destinations in Bali, tourist visits to Ubud are increasing, demanding the provision of various tourism facilities. MacRae (1997) confirms that the phenomenon of commodification of land in Ubud has occurred since the beginning of the development of rural tourism in this area until now [14].

The presence of tourism has consequences for the people of Ubud. That is, the 
community is faced with two choices, namely capturing opportunities created by tourism or seizing them. Capturing opportunities has the potential to ignore ecological wisdom, such as the commodification of traditional open spaces. Not taking full advantage of the opportunities available gives the impression that opportunities offered by the tourism industry are ignored.

In capturing that opportunity, traditional open space is no longer interpreted as a social space, but as a space that has economic value. In this case the meaning of space has shifted from spatial patterns to planning patterns to get money. The presence of tourists has demanded provision of various accommodation facilities. In order to meet the demands of tourists, the community is intensifying the commodification of traditional open space as a business space attempting to fulfill its economic lust and libido.

Commodification is not only carried out by economic actors as capital owners, even local people do the same. As stated by (informant 3), the presence of tourists in Ubud is an opportunity for the community to offer a variety of services to meet the needs of tourists, such as building art shops, souvenir shops, cafes etc. by utilizing the spaces or lands they have. Meanwhile (informant 1) said that in meeting the increasingly complex demands of life, each individual is required to be able to develop themselves. The establishment of Ubud as a tourism destination is an opportunity. This opportunity is utilized as optimally as possible so that the economic benefits of tourism can be enjoyed and felt by the community. In developing this business, the community uses its space and land. We, as village officials, do not have the right to prohibit people from using their own space or land.

Indisputably, since the prehistoric times various tribes living throughout the archipelago have respected the spirit of nature and the power of the earth, whereby they likened it to a mother who gives life, as a goddess of nature and the environment. The land for Balinese people is Mother Earth seen as a sacred property that must be maintained and conserved. Land is considered as a gift from Ida Sang Hyang Widhi Wasa (Hindu God), which must be maintained and cared for to be passed on from generation to generation. Land ethics which contains obligations to the environment, including the obligation to love and respect the land together with its various values. Therefore, Leopold (2001) clarifies that the land is not seen as a commodity that can be freely traded in a free market with mere economic calculations [15].

Suwasthawa, and Cantika (1991) explain that every action or behavior born out of creativity, taste, and human intention always reflects on atita (the past), wartamana (the present), and nagata (the future) [1]. Fay (2002) adds that this temporal dimension has a narrative structure, namely the beginning is the past, the middle is the present, and the end is the future [16]. In relation to culture and spatial planning, as well as how spatial planning is done, Suparlan (2004) describes that humans actually create a functional cultural environment as a container for certain activities in an effort to fulfill their daily needs [7]. 
Open space is a real manifestation of harmony in Tri Hitakarana philosophy, because open space is a site for social interaction, supporting environmental sustainability and a place to perform religious rituals collectively. Brata (2014) and Kato, et al. (2019) describe that Good traditional open space can promote social cohesion, health, happiness, prosperity for the community, and environmental sustainability [5] [13]. Therefore, traditional open spaces must be accessible to all layers of society.

Mudana (2005) and Pujaastawa (2011) define that space is a social arena with a variety of interests. Conflicts and uncertainties will always arise and cannot be avoided [10] [11]. The conflict between central policy with regional expectations and interests, between economic growth and equity, between physical development and the preservation of traditional open spaces are inevitable. All of these conflicts will always arise if there is no meeting point between the parties concerned (the government and the owner of the capital). Interviews with informants (1) showed that if there is a conflict between economic actors or capital owners and community members, we as Ubud village officials act as mediators by issuing agreements without anyone feeling pressured or disadvantaged. For example, economic actors or capital owners are welcome to build and carry out their business activities, but are obliged to respect community members as owners of the area so that harmonious relations can still be maintained. For example the owner of the capital must provide employment opportunities in his company as long as the competencies possessed by the citizens are in accordance with the needs of his company.

Brata (2014), Sukawati (2008), Bawa (2002), and Adhika (2011) explain that if economic interests are more highlighted, then there will be concern about the disappearance of traditional open spaces, both in the form of telajakan, playgrounds, empty land, tegal suci (holy garden), alun-alun (city parks), paddy fields, cliffs, teba (backyard) and even cemetery [5] [8] [9] [12]. As a matter of fact, in the human life cycle from birth to death, the presence of traditional open space is felt as a very necessary need.

In hindsight, space emerges as a social product created by people (agents) who have control over it. Social relations create space, but more importantly, social space is a social product. Social space has a long logic to be self-explanatory. Socially, space becomes a means of achieving and creating control. Space is constructed in such a way to become a means of thought and action. In this context, space is produced in such a way as to perpetuate power and create dominance. However, it should be noted that regardless of the reason and purpose of public space, it is not merchandise, it is not suitable to be commodified for the sake of certain provocative acquisition strategies.

The realization of spatial and housing patterns in the Ubud community is closely related to the attitudes and views of the Balinese people in general, who always place religion, belief systems, and customs as aspects that underlie their lives. Through their religious teachings humans harmonize their relationship 
with the universe, that is, between the bhuana agung (macrocosm) and bhuanaalit (microcosm). Suwasthawa and Cantika (1991) explain that relationship between humans which is the area of bhuanaalit and universe which is the place to be maintained so that it remains in a harmonious state like the relationship between manik (fetus) and cecupu (mother's womb) [1], Leopold (2001) adds that all forming part of environmental ethics [15]. Interviews with informants (1) revealed that there was concern that commodification of traditional open spaces would be excessive without regard to local wisdom, which would lead the destruction of environmental ecosystems. However, as village officials, we do not have the authority to forbid people from commodifying their land which is their own right. We, as village officials, have an obligation to remind both the community and the owners of the capital when building tourism facilities not to violate existing regulations.

The interview with the informant (2) revealed that in building tourism facilities they need space and land as a place of business. People sell their lands, which is an opportunity for us as capital owners to buy the lands they offer. If the land has become ours, then we have the full right to use these lands to build various tourism facilities needed by tourists.

The results of interviews with informants (1) showed that there had been mimicry behavior among the Ubud community. When neighbors carry out commodification of their space and land, their neighbors unwittingly do the same without clear planning, but are only solely encouraged to earn money. After they get money from the sale or rent of their land, they do not have the ability to manage the money; eventually the money is used to buy consumptive needs.

Related to those things society has turned into a market-culture, hedonist, and consumerism society. In this kind of society, people live not only to fulfill their basic needs, but also to fulfill their social and psychological needs. Shifting patterns of daily life are represented through lifestyle as part of the demands and development of modern life. Lifestyle that is influenced by global culture causes the exploitation of resources, it includes exploiting traditional open spaces to meet their needs.

Duncan (1997) describes that humans no longer act for something that is of value for themselves or for mutual needs, but they act only if they can make money [17]. Today there is a tendency for land to be treated as an economic commodity. Capital owners buy paddy fields which they then convert into hotels, bungalows, restaurants, cafes. This has resulted in the land becoming increasingly scarce and expensive, which in turn leads to fierce competition in getting the land. In fact, it is realized that land cannot be produced or created.

The functioning of paddy fields has an impact on the loss of green open space, the loss of various biota in the rice fields. Consequently the environmental ecosystem is damaged. This fact was agreed upon by the informant (3), who stated that, before the paddy fields turned into tourism facility we found it was easy to find sarwa gumatat-gumitit (various biota) that lived in rice fields such as: eels, 
snails, snakes, rice fields etc. However, it is difficult to find them currently. [Figure 2] Showing an example of land convension from rice paddy field into tourism facilities.

Cliffs and river banks have been transformed into tourism facilities, so that green open space has disappeared or water catchment areas are decreasing and even disappear. This fact triggers damage to watershed ecosystems, and consequently the river's water supply decreases. This means that environmental ethics are disobeyed because humans are no longer social creatures (homo socieus), yet they have turned into homo economicus creatures. [Figure 3] An example of rivers that have been functioned as tourism facilities caused the lost of open spaces, polluted river water, and also caused land slides, damaged ecosystem.

Domestic property has transformed into a home stay as a place to stay for tourists. Front yard has an extra function as a place to display art items like a show room. City park has changed into a night market. The front yard of temple, houses, cemetery have now an added function as a new public facility container, as a place to install electric substations, telephone poles, clean water meters, automatic teller machines (ATMs), parking lots, minimarkets, internet cafes, mini gas stations, and even as a place to install advertising billboards ranging from a variety of fast food products, various beauty accessories to general election billboards. [Figure 4] Showing traditional open space, entrance of housing, house yards as places for selling soveniours needed tourists.

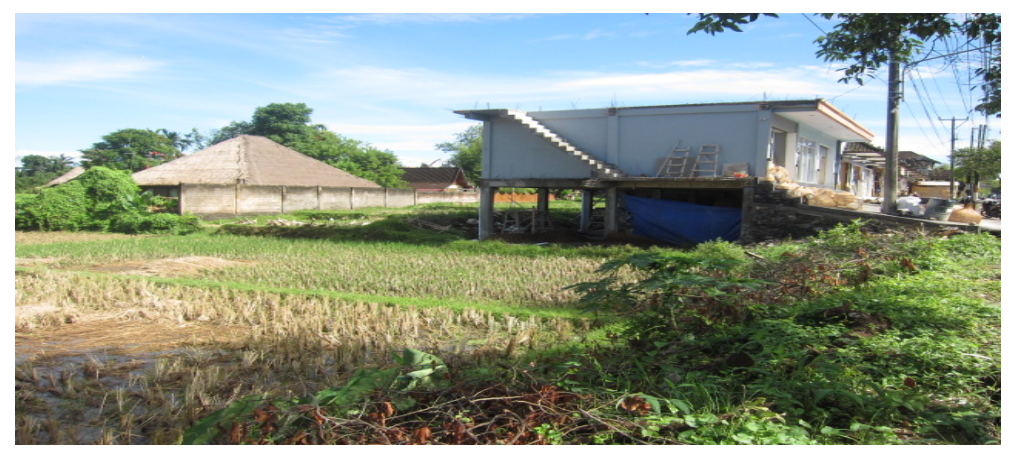

Figure 2. Functioning rice fields become tourism facilities, Photo taken by Brata, 2018.

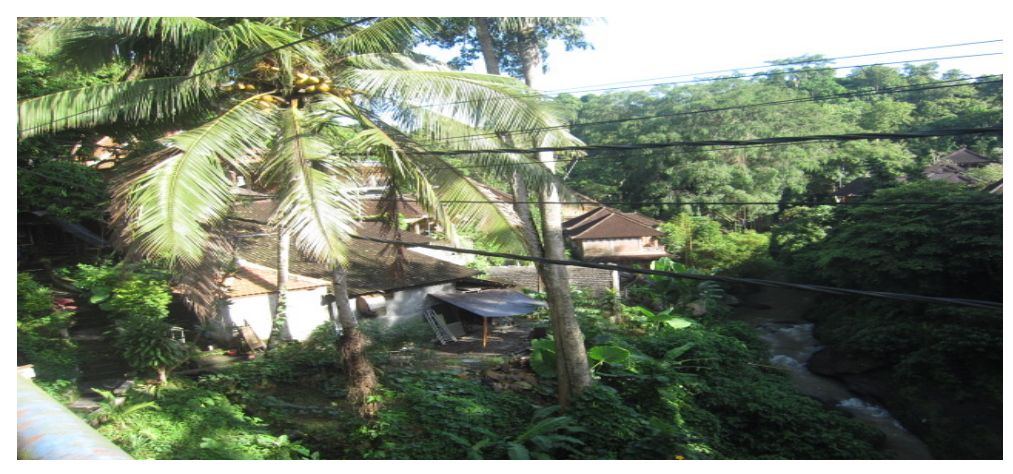

Figure 3. Cliffs function as a hotel, cafe and other tourism facilities, Photo taken by Brata, 2018. 


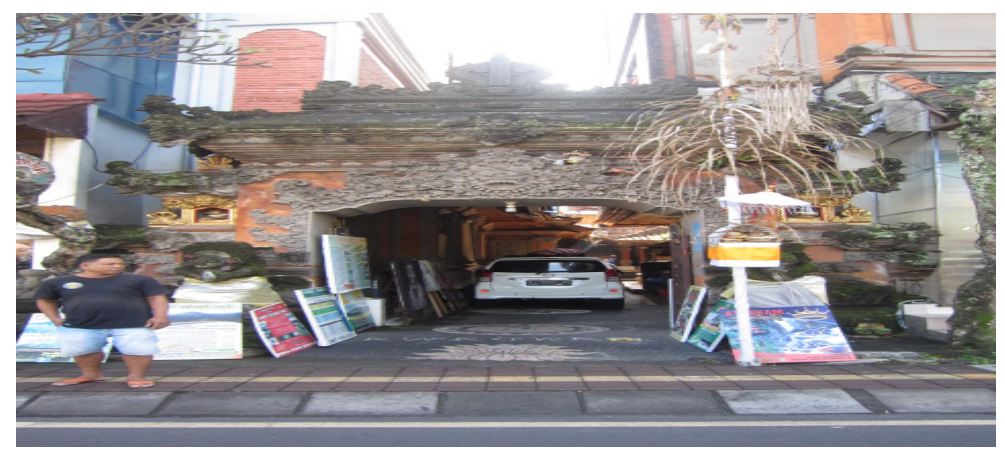

Figure 4. Telajakan, entrance of the house and natah functioned to display various craft arts, Photo taken by Brata, 2018.

The road functions as a parking space for motorbikes and cars, resulting in traffic congestion that cannot be avoided. What is more, even sidewalks are used as a parking space, and even used as a place to display various craft (art) products, making pedestrians very difficult to pass on the sidewalk. This fact is certainly at risk for pedestrian safety.

Duncan (1997) explains that the land which belongs to a temple (ulayat land), empty land, karang embang is often regarded as an unproductive land that is less functional or less useful, eventually being rented to get money, which gives the impression that anything is worth selling to get money [17]. In the capitalist economic system, the value that the market player wants to produce is the exchange rate rather than the use value, meaning that people commodify traditional open space not because they want to use it for business activities, but rather they want to rent it out to get high profits. On the contracted land various facilities are built according to market tastes (capital owners). As a result, there is a tendency for the development of various facilities that are poorly controlled, so that they appear to be slum buildings. Strangely, many illegal buildings are not regulated, while many buildings that violate the rules are not acted on according to existing regulations.

It is inappropriate for land to be contested in a free market as a mere economic commodity. Land should be seen as a social object, and it would even be better if it is utilized as an instrument of development for the realization of a civilized and cultured society. Not all public spaces must be seen as markets, not merely as a place of transaction of needs and interests, nor as a place to educate themselves to see that everything in the universe can be commodified. Whatever the reasons and objectives, public space is not a commodity, so it is not appropriate to be commodified for a momentary economic purpose.

\section{Conclusion}

Based on the above discussion, some conclusions can be drawn as follows. First, the development of commodification of traditional open space in Ubud Village is inseparable from the influence of tourism as part of global capitalism to capitalize on various environmental resources. Second, the commodification of 
space occurring in Ubud tends to lead to a shift in traditional spatial values following the willingness of investors as distribution agents to transform traditional spaces into economic spaces to meet market demand or the taste of consumers (tourists). Three, the transformation of space functions from traditional space identity features into spatial planning to fulfill economic libido has implications for ignoring environmental ethics.

\section{Acknowledgements}

On this occasion the author expressed his gratitude to the Rector through the Institute for Research and Community Service Mahasaraswati University Denpasar, who gave permission and provided facilities from the beginning of the study until the research was successfully completed.

\section{Conflicts of Interest}

The authors declare no conflicts of interest regarding the publication of this paper.

\section{References}

[1] Suwasthawa Dharmayuda dan I. W. Koti Cantika (1991) Filsafat Adat Bali. Upada Sastra, Denpasar.

[2] Picard, M. (2006) Bali: Cultural Tourism and Touristik Culture Trans by Diana Darling. Archipelago Press, Singapore.

[3] Barker, C. (2009) Cultural Studies, Teori dan Praktek. Kreas Wacana, Yogyakarta.

[4] Fairclough, N. (1995) Discourse and Sicial Change. Polity Press, Cambridge.

[5] Brata, I.B. (2014) Commodification of Telajakan at Ubud Village, Gianyar, Bali. E-Journal of Cultural Studies, 7, 1-6. http://ojs.unud.ac.id/index.php/ecs/article/view/8417

[6] Brata, I.B. and Gd Pemayun, A.A. (2018) Human Resource Competency Tourism Bali Together with ASEAN Economic Community" International Research Journal of Management, IT and Social Sciences, 5, 186-194. https://doi.org/10.21744/irjmis.v5i2.638

[7] Suparlan, P. (2004) Masyarakat dan Kebudayaan Perkotaan: Perspektif, Antropologi Perkotaan. Yayasan YPKIK, Jakarta.

[8] Sukawati, T.O.A.A. (2008) Perubahan Spasial Desa Adat Ubud, Gianyar Bali dalam Era Globalisasi: Sebuah Kajian Budaya. Disertasi, Pascasarjana Udayana, Denpasar.

[9] Bawa, P.W. (2002) Pemanfaatan Tebing di Sepanjang Tepi Sungai Ayung dalam Industri Pariwisata dan Implikasinya terhadap Pelestarian Lingkungan. Thesis, Pascasarjana Unud, Denpasar.

[10] Mudana, I.G. (2005) Pembangunan Bali Nirwana Resort di Kawasan Tanah Lot: Hegemoni dn Perlawanan di Desa Braban Tabanan Bali. Disertasi, Pascasarjana Unud, Denpasar.

[11] Pujaastawa, I.B.G. (2011) Komodifikasi Lingkungan dan Implikasinya terhadap Sistem Sosiokultural di Desa Taro. Disertasi, Pascasarjana Unud, Denpasar.

[12] Adhika, I.M. (2011) Komodifikasi dalam Era Globalisasi Kawasan Suci Pura Uluwatu di Kuta Selatan Badung. Disertasi, Pascasarjana Unud, Denpasar. 
[13] Kato, S., Kosuke, H., Darmadi, A.A., Dwijendra, N.K.A. and Suprapta, D.N. (2019) Functional Analysis of Telajakan Plants and Space in Northern Denpasar, Bali, Indonesia. Open Journal of Ecology, 9, 15-24. http://www.scirp.org./journal/oje https://doi.org/10.4236/oje.2019.92002

[14] MacRae, G.S. (1997) Economy, Ritual and History in Balinese Tourist Town. Thesis of Requirement for Degree of Doctor of Philosophy.

[15] Leopold, A. (2001) Etika Lingkungan. In: Dkk, D.L.M., Ed., Applied Ethics: A Multicultural Approach (Penerjemah: Sinta Carolina Dkk). PT. Tiara Wacana, Yogyakarta, 210.

[16] Fay, B. (2002) Contemporary Philosophy of Social Science (Penerjemah M Muhith). Jendela, Yogyakarta.

[17] Duncan, H.D. (1997) The Establishment of Money as Symbol of Community Life; Money as a Form of Transcendence (Alih Bahasa: Kiki Alfian). Pustaka Pelajar, Yogyakarta. 